\title{
RESENHA
}

\section{INTEGRATED COASTAL AND OCEAN MANAGEMENT: CONCEPTS AND PRACTICES}

\author{
BILIANA Cicin-SAIN e RoBert W. KNECHT \\ Washington: Island Press, 1998.
}

Sem dúvida, quando o assunto é gerenciamento integrado da zona costeira os pesquisadores do Center for Study of Marine Policy, da Universidade de Delaware, são considerados os maiores expoentes nessa temática. Esse livro é considerado a cartilha para se entender as territorialidades que envolvem a zona costeira, seus usos e conflitos. Cabe salientar, em primeiro lugar, a participação da Academia numa área, que em nosso país ficou a cargo da Comissão Interministerial para os Recursos do Mar, denominada Política Marítima ou, como gostam de tratar, de Poder Marítimo, talvez, pela própria formação histórica da nossa nação. É fundamental que essa discussão transponha as esferas públicas e passe a ser da sociedade, como é típica nos países que alcançaram a sua soberania através do comércio marítimo, em todas as suas formas, inclusive com a pirataria. A importância dada ao shipping, termo que na língua inglesa denomina todas as atividades que envolvem o transporte, o comércio e as atividades voltadas para o mar, é explicada pela participação da sociedade desses países nos assuntos ligados ao seu "território marítimo", sendo esse livro, um exemplo claro do alto nível de discussão que essa temática adquiriu nessas nações.

O livro inicia em sua primeira parte abordando as definições e os conceitos fundamentais para o gerenciamento integrado da zona costeira, levantando os usos e os conflitos dos espaços costeiros. Uma grande coletânea dos conflitos é referenciada nessa primeira parte, inclusive, relacionando o país e as atividades que mutuamente se conflitam. Dando continuidade, em sua segunda parte os autores avaliam o gerenciamento integrado da zona costeira nas entidades 
supranacionais como ONU, e os preceitos acordados na convenção de direitos do mar em 1973 e 1982. Analisam também outras agendas que diretamente ou indiretamente se correlacionam com os recursos costeiros, e são elas: a Declaração do Rio para o Meio Ambiente e Desenvolvimento, a Convenção da Diversidade Biológica e a Agenda 21 em seu capítulo 17 que trata da zona costeira incluindo a zona econômica exclusiva.

A terceira parte é composta por um guia prático de implementação para o gerenciamento integrado da zona costeira, onde ressalta a importância da participação da sociedade civil organizada nos ordenamentos dos espaços costeiros. Nesse guia de implementação do GIZC os autores destacam a importância dos aspectos legais que envolvem as políticas para a zona costeira, além da importância dos trabalhos científicos para o amparo desses programas. Cabe ressaltar que a terceira parte do livro termina com a metodologia de implementação, operação e valoração dos planos de intervenção para a zona costeira.

$\mathrm{Na}$ quarta parte desse livro "cartilha" encerra com a apresentação de inúmeros estudos de caso, comparando as diversas práticas de implementação do GIZC, em vinte e dois diferentes países, classificados segundo o critério de nações desenvolvidas, com médio desenvolvimento e em desenvolvimento. Estão inseridas as experiências de países como Estados Unidos, Inglaterra, França. Espanha, Holanda, Brasil, Tailândia, Equador, China, Índia e Filipinas.

O livro é a maior coletânea de assuntos relacionados ao gerenciamento costeiro, um tema considerado recente. O Brasil, apesar de ser um país voltado para o litoral, não possui uma tradição marítima, o Programa Nacional de Gerenciamento Costeiro, que foi ratificado pela Lei Federal $\mathrm{n}^{\circ} 7661 \mathrm{em} 1988$, somente foi sancionado em dezembro de 2004 pelo Decreto Federal $n^{\circ} 5300$, demonstrando uma falta de interesse do Poder Público e do conhecimento por parte da sociedade para os assuntos relacionados à zona costeira. 